\title{
A VÁROSI MIKROTEREK TÁRSADALOMTÖRTÉNETE
}

\section{GYÁNI GÁBOR}

A város mint tér-adottság tudományos problémaként az 1920-as évek amerikai városszociológiájában merült föl elsôként. Az akkor és ott paradigmatikusan megfogalmazott tematika hagyományozódott tovább, megszabva a városi tér fogalmi kereteit. A kifejezetten empirikus vizsgálatokra irányuló Chicagó-i szociológiai iskola a modern nagyváros funkcionális övezeteinek, társadalmi tereinek a feltárását ambicionálta, és arra keresett választ, hogy milyen folyamatok zajlanak ezen a szerkezeten belül. Nagyon leegyszerũsítve, ez a fajta, nagy hagyománnyal rendelkezô és ma is virágzó városkutatás a népesség, a városlakók (lakóhelyi) térbeli eloszlását és annak módosulásait helyezi vizsgálódásai előterébe.

Nem igényel hosszasabb bizonyítást, hogy a város társadalmi terét nem meríti ki - fogalmilag sem - a csupán a lakóhelyi megoszlást tematizáló szemléletmód. Fölvethetố, s ma már gazdag irodalom bázisán eredményesen vizsgálható is a társadalmi tér, mint a legsokrétúbb egyéni és csoportos tevékenységek kerete és determinánsa, az ilyen minóségében játszott szerep értelme (tehát a neki tulajdonított jelentés, normatív fogalom) és gyakorlati funkciója. Továbbá: jelentôsen kitágítható, sốt egyenesen kitágítandó a társadalmi tér fogalma azzal a kifejezett céllal, hogy minden (városi) térforma benne foglaltassék. Miben különbözik az utóbb jelzett új tudományos érdeklổdés a , hagyományos" városökológiától? A pusztán csak tematikus különbséget gyakorlati példán mutatom be. A lakóhelyi elkülönülésre és a vele kapcsolatos népességmozgásokra koncentráló városszociológia és társadalomtörténet vagy társadalomföldrajz térfogalmától elszakadó megközelítés figyelme felöleli a köz- és a magánterek mindegyikét, vizsgálati problémaként tételezve $\mathrm{pl}$. az utcát, a parkot vagy a kaszinót és klubot. A társadalomantropológia kérdésfeltevéseinek hatására a különféle térformák tényleges igénybevételének, használatuk módjånak és sũrũségének a vizsgálatán túl, fontos szempontként merül föl a konkrét tereknek tulajdonított jelentés megismerése is. Ennek megfelelóen állíthatjuk a modern nagyváros kutatása során elemzésünk középpontjába a ,,köz" és a ,,magán” dichotóm fogalompárját, mint amelyik alapvetô rendezőelve a szociális tér bármely formájának. Mindezek elốrebocsátásával jelezni kívántuk, hogy az itt következở gondolatmenet miben és hol jár más úton, mint a városi tér megszokott kérdésfölvetése.

\section{A köz- és a magántér fogalma és strukturálódása}

Európai perspektívában szorosabban a 18. század derekától, végétôl lehetünk tanúi a magánés a közélet mind határozottabb szétválásának, kettôjük ellentétbe kerülésének. A szociábilis, kötetlen társas viselkedés ennek során bekövetkezố kiszorulása (jóllehet nem maradéktalan eltûnése) a nyilvánosság számára fenntartott viselkedésből, a ,,közterekrổ”, egyúttal azt ered- 
ményezte, hogy az a magánélettel, a családdal vált eggyé, visszaszorult az otthon falai közé, a legszúkebb privát térbe. Bármennyire is vonzó lenne hosszan taglalni a ,,köz” és a ,,magán” fogalmainak az élet mindmegannyi területén tárgyiasuló differenciálódását, a folyamatot csupán egyetlen összefüggésben vehetjük most szemügyre: a nagyvárosi nyilvánosság funkcionális átalakulásában.

Mit kell azon érteni, hogy a nagyváros nyilvánosság-szférája funkcionálisan egyszerűsödik, miközben határozottan elkülönülnek egymástól a kifejezetten a magán és a kifejezetten a nyilvános viselkedésnek fenntartott téralakzatok? Mindenekelốtt arra kell itt gondolni, hogy pl. az utcai és egyéb köztér nem tolerálja többé a magánéleti megnyilvánulásokat, vagy legalábbis csökken minden magánéletinek minősülố életfunkció ottani megjelenésének az esélye. Holott a megelổzỏ századokban az utca minden további nélkül egyaránt szolgált a köz- és a magánélet (persze ekként talán nem is definiált) terepe gyanánt. ,Ez a középkori utca - jegyzi meg Ariés -, akár a mai arab utca, nem ellentétes a magánélet intimitásával; e magánélet külsô meghoszszabbítása, a munka és a társadalmi kapcsolatok családias kerete. Amikor a múvészek viszonylag megkésve megpróbálják a magánéletet ábrázolni, elổször az utcán ragadják meg, mielốtt követnék a ház belsejébe. Nagyon is lehetséges, hogy a magánélet legalább annyira, ha nem inkább az utcán zajlott, mint a házban."'

Az individualizmus szelleme, az intimitás belsổ szükségletté válása, az életviszonyok materiális elemeinek a fejlổdése (a civilizálódás) és egyéb fejlemények nyomán mindinkább megszilárdult a világ külsổre és belsốre szétágazó rendje. A 19. század végén azután szinte általános az az érzület, hogy az egyes egyént komolyan veszélyezteti, fizikai és erkölcsi tekintetben egyaránt sérti az utcai élet nyilvánossága (Bedarida-Sutcliffe 1980). A szóban forgó folyamat az angolszász országokban válik végletessé (viktorianizmus), jóllehet mindenhol mélyreható következményekkel jár a nagyvárosok, elsổ helyen a fởvárosok tárgyi felépítésében és térszerkezetében. Egészen más külsố illette meg - stilusát tekintve is - a középületeket, mint a csak lakás céljára emelt közönséges épületeket; ráadásul az egyik és a másik térbelileg is jól elkülönült egymástól, mint lakónegyed és üzleti vagy kormányzati negyed.

De nemcsak errốl van szó. A körút és a sugárút, a 19. századi modern urbanitás e két szimbólumértékũ zseniális találmánya s egyúttal megtestesülése, gyakorlati funkcióknak is kiválóan megfelelt. Túl azon a közismert katonai megfontoláson, hogy az utak kiszélesítésével és a külvárosok rendszertelenül épített negyedein való keresztülvezetésével hatékonyan vessenek gátat a lázadásra hajlamos városi népesség barrikádépítổ lehetôségeinek, ez a városi térszerkezet (utcahálózat) volt egyszersmind a legmegfelelốbb a nagyvárosi ember- és árutömeg gyors áramlásához-áramoltatásához is. Az utca e formájával vált valósággá a jármũvek elôretörése a gyalogosok rovására, ekkor és itt vette kezdetét az utcának egyoldalúan a jármúforgalom céljaira történô kisajátítása. Ez viszont parancsoló követelménnyé is tette a forgalomban résztvevốk, az emberek és a jármũvek összehangolt mozgatását. Ez a szabályozás arra irányult (és irányul ma is), hogy fennakadás nélkül biztosítva legyen a mozgások koordinált folytonossága. A folytonosság fenntartásának szükségessége minốíti funkciótlannak a puszta lézengést, a tömegmozgásokat akadályozó , ,értelmetlen" utcai jelenlétet. Az össze-vissza tartó mozgások koordinálását tekintve pedig az 1905 körül elsôként az Egyesült Államokban alkalmazott közlekedési lámpa hozta meg - távlatosan - a várva várt technikai megoldást. Az így szabaddá tett, ugyanakkor megrendszabályozott utcai (körúti és sugárúti) ember- és jármưforgalom ettốl a pilla- 
nattól kezdốdốen felrúgott minden idô- és térbeli korlátot; a város összes zugába behatolva a maga tempóját kényszerítette rá a városlakók idốbeosztására, hogy ,,mozgó káosszá” változtassa, lényegítse át a modern nagyváros, a metropolisz életét (Berman 1982).

Az imént mondottakból következik, hogy az utca mint a nyilvánosság színtere aligha játszhat többé átfogó szerepet; immáron nemcsak a magánéleti, de a szociabilitást még megengedó "közéleti" viselkedésformáknak is mindinkább az ellenségévé alakul át. A találóan a sivatag képzetével jellemzett századvégi párizsi körút és sugárút ${ }^{2}$ mellett, ám térben tổle elkülönülve, így kezdtek megsokszorozódni azok a nyilvános társasélet céljait szolgáló közterek, amelyek majd pótolják az utca kiesổ nyilvánosságát. Azt nem állítjuk, hogy a modern, a 19. században születổ nagyváros elsổként hozta létre a közterület egymástól egészen elváló, speciális résztevékenységeknek fenntartott mikrotereit. Korábban sem volt teljesen ismeretlen, hogy a köztér adott válfaja egyetlen meghatározott tevékenységet szolgált ki. Ami viszont kétségkívül újdonság, az a specializált terek számbeli megszaporodása és merev "szakosodása" (HohenbergLees 1985).

A résztevékenységeknek megfelelổ egyfunkciós mikroterek kialakulása mögött döntố tényezớként hatott a munka- és a lakhely terjedő (véglegessé soha nem váló) szétválása, tudniillik, hogy a családi gazdaság mind többek életében családi bérgazdasággá, majd családi fogyasztási gazdasággá alakult át, s a munkavégzés térbelileg is az otthonon kívül koncentrálódott. A városi nyîlt terek használatát illetốen ennek mélyreható következményei vannak. De túl ezen, városi parkok, folyó- és tópartok, hegyek és városkörnyéki erdốk stb. adtak fokozatosan otthont a természeti környezettől mindinkább elidegenedett városlakók munka utáni idốtöltésének, hogy a természettel való újratalálkozás vágyának hódolhassanak. A hétvégi kirándulás szokásának elterjedése igen prózai velejárója a modern nagyvárosi ember életvitelének. ,,A szabadidós tevékenységek modelljei nemcsak a városon belüli lehetốségek és magatartások változásait tükrözték vissza, hanem az azon túli környezethez való új viszonyt is. Ebben az idốszakban (az 1920-as években - Gy. G.) az olyan nyílt terekre, mint a Casa de Campo vagy a Sierra Navacerrada, történổ kijárások mind divatosabbakká lettek. Hegymászás, síelés és a természetimádat. . . mind részei lettek a liberális polgárságot képviselổ ifjak életmódjának." ${ }^{3}$ - olvassuk egy Madridról szóló tanulmányban.

Továbbá: adott épületek afféle közenteriơrök módján, a félnyil vánosság keretei között kezdik kielégíteni a társas együttlét, a közvetlen, ám nyilvános érintkezés nem lankadó szükségletét. Itt, ezekben az épületekben rendezkednek be a társadalom vagyoni és presztízs-hierarchiáját leképezố klubok, kaszinók, olvasókörök, munkásotthonok, egyéb társaskörök nyilvánosságfórumai. Szintén a nyilvánosság zárt térbe kényszerített formájaként honosodik meg a kulturális intézmények egész sora, a régóta létezổ szinházakhoz felzárkózó közkönyvtár, képtár, múzeum vagy a cirkusz és századunkban a mozi stb. Látogatóik bennük egyéni érdeklớdésüket egyénileg, nem feltétlenül közösségi módon, viszont elvileg mindenki által egyaránt hozzáférhetổ helyen (közös helyiségben) elégíthetik ki. Aminek egyedüli akadályát csak az képezheti, hogy a látogatásukért (használatukért) követelt anyagi hozzájárulást, a belépti díjat széles néprétegek sokáig nem tudják megfizetni.

A nyilvánosság szociális-fizikai terének újabb sajátos változatát a fogyasztási szükségletek egyéni, de közösségi keretek közötti kiszolgálására specializált éttermek, kocsmák, bárok, egyéb énekes vagy táncos szórakozóhelyek, valamint az üzletek és kivált az áruház alkotják. 
Nem feledhetốk végül a , ,közlekedő ember” funkcionális térigényébốl megszületổ nagyvárosi vasúti pályaudvarok, melyekhez századunkban buszpályaudvarok és a repülôterek csatlakoznak. A vasúti pályaudvarok ugyan csak egyetlen funkció céljából épültek a múlt század derekán és második felében, gyakorlatilag viszont tágabb nyilvánosság-szerepet olvasztottak magukba. A pályaudvari élet elengedhetetlen kellékei, az étterem (helyesebben csak resti), a postahivatal, a boltok stb. mind-mind hozzájárulnak ezen intézmény funkciógazdagodásához.

A magánélettốl elkülönülớ közszférának és a köztérnek ez a szétaprózódása ugyanakkor oldotta is a nyilvános viselkedést erôsen gúzsba kötổ polgári kódokat. Az utóbbiak az önfegyelem, a visszafogottság, és az idegenek, tehát a nagyvárosok tömegtársadalmát alkotó individuumok közötti személyes érintkezés erổs korlátozása jegyében változtatták ,, holt térré” a nyilvános megjelenés színtereit (Sennett 1977). Persze csak lazított e kódok merevségén, de nem helyezte azokat hatályon kívül. Ám a változatok vizsgálata nem tartozik futó áttekintésünk körébe. Annyit azért megjegyezhetünk, hogy a viselkedés, a nyilvánosság számára szóló magatartás új értelme korántsem tekinthetô spontán folyamatok eredményének, de nagy része volt benne az irányításnak, a hatalmi eszközökkel kikényszerített alkalmazkodásnak, a morális ideológizálással kísért rendổri erổszaknak. Beszédes példái ennek a köztér használatával kapcsolatban megfogalmazott helyi szabályozások, városi törvények és maga a mindennapi rendổi gyakorlat.

Igencsak leegyszerưsítenénk a képet, ha a ,,magán” és a ,,köz” fogalmainak elválását elintézettnek gondolnánk az otthon és a rajta kívüli világ kettổsségével. Nemcsak azért nem kielégítố ez a beállítás, mert maga a külvilág is - láthattuk - különbözổ minôségú terek sokaságára osztódott szét, melyek a merev oppozícióban szemlélt magán- és közszféra kisebb vagy nagyobb fokú elegyítését valósították meg. Ha az utcát tekintjük a köztér legszemélytelenebb, legsemlegesebb megnyilvánulásának, mennyivel több a személyes és szociábilis elem az olyan félnyilvános köztérben, mint amilyen a kávéház, nem is beszélve pl. az exkluzív klubok, kaszinók világáról. De jellemzổ különbségek állhatnak fenn e tekintetben ugyanazon ,,köztér" használói között is. Merốben másként viselkedik az étteremben (szórakozóhelyen) az alkalmi és a törzsvendég, illetổleg az, akinek ez a munkahelye (pincér). Az utóbb említett személy számára ez a semleges, idegenekkel benépesített köztér már szinte személyes jelleget ölt, amelyben "otthon" van, amely tehát már inkább félprivátnak bizonyul számára (Lofland 1973).

De azért sem elégedhetünk meg az otthon és a rajta kívüli világ kettốsségének puszta feltételezésével, mert a privátnak számító otthoni világ sem egészen mentes a ,,köz” és a ,magán" dichotómiájától. Újfent az angolszász országok múlt századi fejleményei mutatják a legplasztikusabban, hogy az otthon falai között is bekövetkezett a terek feldarabolása s megsokszorozódása, amelynek egyik vonatkozásban jól megfeleltethetố a magán- és a közszféra differenciálódása. A tágas közép-és nagypolgári lakásokban, majd idôvel a kontinensen megszokottnál jóval nagyobb munkáslakásokban is megfigyelhetô a helyiségek, a szobák funkcionális megosztására való törekvés. Mindenekelốtt elkülönült egymástól a család és a háztartás lakrésze, az utóbbi, a konyhán kívül, felölelte a cselédszemélyzet szobáit is. A családi lakrészt tovább differenciálta a kor és a nem: a felnốttek éppúgy elkülönültek a térben a gyerekektôl, amennyire a felnốtt férfi és nố szintén külön húzódott a lakás egy-egy szögletébe. Sớt, a közös használatban álló helyiségek is szegregálódtak a nemek szerint: az ebédlố inkább a férfiak, a szalon inkább a nớk szférájához tartozott. Számunkra itt most mégis az a döntổ, hogy rámutassunk: az otthon privát terén belül is kialakult a , magán” és a ,,köz” megosztottsága. A ,családi szobák” állományán belül a hálószoba képviselte a teljes intimitást és a szalonban valósult meg az otthonba 
becsempészett nyilvános tér. Már maga a helyiség eredete is beszédesen vall errôl. Mint Grier az amerikai szalonokról írott könyvében igazolja, a lakások szalonjait idóben megelốzte és megelôlegezte a nyilvános szalon. Ez utóbbi mint szállodák, vasúti szerelvények, gốzhajók tartozéka, igen gyakori a múlt század második felében az Egyesült Államokban. Ezeknek a szalonoknak alapvetô szimbolikus funkciójuk volt, hogy a középosztályi kifinomultság és elkülönültség látható megnyilvánulásaiként szolgáltak (Grier 1989).

Nem állítom, hogy a középosztályi otthonok univerzális lakrésze, a szalon mindenhol a nyilvános szalonoknak volt leszármazottja. Tény viszont, hogy értelmük és szerepük mindenhol teljesen azonos: csak és kizárólag házi társas összejövetelek céljaira használják, köznapi használatára nincsen példa. Mint az otthon külvilág felé fordított arca, a szalon különösen alkalmas a hivalkodásra, a magamutogatásra, a reprezentációra. Innen ered, hogy ebbe a helyiségbe zsúfolják a legtöbb értékes bútort és dekórumot, ide összpontosul egy-egy otthon ingóságából az értékek zöme (Clark 1976; Gyáni 1989).

Általánosságban érvényes, jegyzi meg Daunton, hogy minél inkább differenciálódik a lakáson belüli tér, annál nagyobb hangsúlyt kap a magán- és a közszféra közötti szigorú különbség (Daunton 1989). De vajon milyen ökológiai struktúra és szociális térszerkezet képezi mindennek a hátterét?

\section{Várostervezés - fertốtlenítés - szegregálás}

Az utca személytelen és semleges voltának fokozatos megteremtése, a 19. század folyamán végig, lankadatlan erôfeszítésekre ösztönözte a hatóságokat. Különösen hatványozottak voltak ezek az erốfeszítések a munkásnegyedeken belül, ahol az utcák, egyéb közterek, sốt nemegyszer a lakások szorosabb hatósági- rendôri felügyelete éppen arra lett volna hivatva, hogy a közszféra polgári normáinak gyakorlati érvényt szerezzen. De miért a fokozott figyelem történetesen itt, és mondjuk nem a belvárosban? Ennek legalább két oka van; egyrészt a nagyvárosok meglehetõsen polarizált társadalmi szerkezete, melyben többnyire az alsóbb, a munkásrétegek, proletár társadalmi csoportok alkotják a számszerú többséget, ám mellettük az átlagost meghaladó mértékben vannak jelen a leggazdagabb, legtöbb hatalmi befolyással és presztízzsel rendelkezỗ vezetô osztályok tagjai. Ebben az éles osztálykülönbségektốl szabdalt városi társadalomban az embercsoportok térbeli elhelyezkedésének kulcsjelentôsége van. Olyannyira, hogy az eltömegesedô, mert népességszámában oly mértékben felduzzadó nagyvárosi társadalomban a puszta tájékozódás, az eligazodás megkívánta megismerés elsốrendũ eszközévé a térbeli lokalizáció válik. Az idegenek világának a boldoguláshoz, a mindennapi életvitelhez szükséges kiismerése már nem hagyatkozhat a puszta vizualitásra; nem elégséges már a gyakorlott szem, az iskolázott tekintet, hogy eligazítson bennünket az idegenek, a nagyváros általunk személyesen nem ismert lakóinak identitása felốl. A test külsố megjelenésének, a ruházat, a gesztusok figyelmes tanulmányozásán alapuló ,,rendszerezés”, a város ,,szövegének” ilyetén ,olvasása” nem lehetséges többé a modern (az ipari korszakban kiteljesedô) nagyvárosban. Fel kell hogy váltsa azt annak megfigyelése és állandó tudatosítása, hogy mi a dolgok térbeli rendje, hogy az ilyen és ilyen identitású (társadalmi hovatartozású) egyének és csoportok, vagy ez és ez a tevékenységforma hol is helyezkedik el a város térképén (Lofland 1973). Ennek a ténynek mint 
tükörnek csak a tárgyi valóságra vonatkoztatva lehet teljes értelme, hiszen arra utal vissza, hogy a nagyvárosok szociális topográfiája a hosszú 19. század évtizedeiben alapvetốen átalakult.

A hatósági figyelem egyoldalú irányának oka másrészt az, hogy az egyes társadalmi makroés mikrocsoportok egymástól eltérôen vélekednek a nyilvánosság jellegéról és határáról, s ennek megfelelően köztéri visel kedésmódjuk szembetưnổ különbségeket mutat. Vegyük elsốként szemügyre a nagyvárosok ökológiai felépítésében bekövetkezett döntố átalakulást, amelynek hatására a nagyvárosi ember a vizuális rendszerezésról kénytelen volt áttérni a térbeli lokalizációra, mint a dolgok és emberek közötti eligazodás fó metódusára.

Már Engels rámutatott, hogy Párizs (vagy más nagyvárosok) "Haussmannosítása", tehát a Haussmann példáját követố gyökeres átépítése következtében a társadalmi osztályok térbelileg a korábbinál távolabb kerültek egymástól. Mint írta: ,,A 'Haussmann' szón azt az általánossá vált gyakorlatot értem, amely abban áll, hogy áttörik a munkáskerületeket, különösen ha nagyvárosaink központjában fekszenek ... Az eredmény mindenütt ugyanaz, akármilyen különbözó is az ok: a legbotrányosabb utcák és kis sikátorok eltünnek ..., máshol azonban nyomban újra keletkeznek, gyakran a legközelebbi szomszédságban."4

A várostervezés eszméjének múlt század közepi megfogalmazása, majd elsớként Párizsban történổ gyakorlati megvalósítása (1853-tól) (Sutcliffe 1979) nem csekély mértékben éppen a felsố és az alsó társadalmi csoportok minden addiginál teljesebb fizikai elkülönítését célozta. Az egyre heterogénebb és zsúfoltabb nagyváros népességének tervezés útján megvalósítandó térbeli hierarchikus újraosztása mögött, más motivációkkal együtt, különösen a járványoktól való páni félelem hatott. Ha volt megfogalmazott érvrendszere, , ,nyelve” a korabeli várostervezésnek és a lakáskérdést problémaként tételezõ szociális reformereknek, az egy alapjában egészségügyi-orvosi szemléletben gyökerezett. A várostervezốk és a lakásnyomor csillapításán elmélkedô-fáradozó reformerek diskurzusa, fogalmi nyelvezete telis-tele volt a fekély, a ragály, tehát az orvosi patológia megannyi egyéb kifejezésének metaforikus használatával. Nem kivétel ez alól maga Haussmann sem, akinek kedvelt metaforája szerint a várostervezố tulajdonképpen az a sebész, aki a város, Párizs testének az egészsége végett kényszerül átfogó sebészi-mû́téti beavatkozásra egész városrészek lerombolása (kivágása, eltávolítása), és újak felépítése (beültetése) útján (Vidler 1978).

S jóllehet a közegészségügyi, vagy inkább társadalom- patológiai szemlélet társadalomalakító vezérelvvé, egyenesen ideológiává magasztosulása joggal hivatkozhatott a 19. századi nagyvárosokat tartósan, több hullámban vissza-visszatéróen sújtó tömegjårványok, fóként a kolera elrettentổ példáira (Evans 1988); igazában mégsem csak errổl volt szó. Igaz, a korban mély beidegzốdések hatottak abba az irányba, hogy a társadalmi jelenségekhez biológiai analógiákon át, hamisítatlan orvosi látásmóddal férkôzzenek közel. S ebben bizonnyal része volt annak is, amit Carlo Ginzburg szellemes tanulmányában állít, hogy ti. a kortárs orvostudomány a humaniórákkal még alapvetốen azonos megismerési modellt képviselt. A korabeli orvoslás szokványos eljárása volt ugyanis, hogy az egyedi közvetlen megfigyelését kvalitatív jellegũ ténymegállapitással, a diagnózis felállításával zárta le (Ginzburg 1980). Jellegénél fogva ez a fajta megismerési , technika” éles különbséget tett jó és rossz, egészséges és egészségtelen, normális és abnormális között. Az emberi világra és annak képzốdményeire alkalmazva pedig úgy mứködött ez a szemléletmód, mint ahogyan Michel Foucault beszél a hatalom ,,normalizálási” technikájáról (Foucault 1979). Magától adódott tehát, hogy a polgári értékek tagadása, vagy 
akár csak az elhanyagolása, az ellenállás velük szemben a mondott értékek táplálói és védelmezởi szemében ne tửnjék másnak, mint puszta eltévelyedésnek, patológikus megnyilvánulásnak, s mint ilyen, jól megragadhatónak tứnt a rendelkezésre álló orvosi- egészségügyi metafórákkal is. , A polgári társadalomreformerek tudatában - írja Ann-Louis Shapiro - a fertôzött kunyhóikból nap mint nap elốbújó városi munkások egyszerre jelentették az egész társadalmat érintố biologiai, morális és politikai veszély forrást ... Nem véletlen, hogy a reformerek egymást átfedô csoportjaiban a lakásügy reformja lett az elsốszámú prioritás, úgy tửnt ugyanis, hogy ez a munkásosztály fertốtlenítésének és pacifikálásának a legígéretesebb módja." ${ }^{5}$

Egy szó mint száz: a tổkés városfejlốdés- és fejlesztés, e folyamat nagyvárosokat érintố része felfokozta a társadalmi rétegek térbeli elkülönülését. Ami Párizst illeti, , ,Haussmann rombolásai, ritka kivételekkel, nem tüntettek el egész negyedeket, de abba az irányba hatottak, hogy egymástól elszigeteljék azokat." ${ }^{6}$ De a francia fớváros mellett, ha talán nem is ilyen látványos módon, teljes újjáépitéssel egybekötve, hasonló folyamat ment végbe Londonban is, ahol a lakosság területi polarizálódása a század végére már hiánytalannak nevezhetổ (Olsen 1986; Jones $\left.1984^{2}\right)$.

És rokon szándékok mozgatták - a katonai és az infrastruktúra modernizálását célzó megfontolások mellett - Bécs várostervezôit is, amikor a Ringstrasse megalkotásával (1860 után) szinte két részre osztották az eddig is e vonal mentén elkülönülô szocio-fizikai városegészt: a körúton belüli arisztokrata és közép-, vagy inkább nagypolgári népességứ, reprezentatív középületekkel teletũzdelt belvárosra, az ún. Ring-zónára, valamint a körutakon kívüli munkások lakta külvárosokra (Olsen 1986; Schorske 1981²; Hanák 1985).

Ami Berlint és Budapestet illeti, a két fôvárosban a szélsố társadalmi rétegek térbeli elkülönítése kevésbé öltött szembeötlổ méreteket, bár jól felismerhetõ nyomai így is létrejöttek az új városkép századvégi megalkotása eredményeként. Hiszen a külön munkásnegyedek a külvárosokban vagy a peremtelepüléseken, majd az ellentétes oldalon, a felsố- és a középosztályok által benépesített belsô városnegyedek fốbb kontúrjai itt is, ott is hamar kirajzolódtak. Mégis: a két ellentétes osztály tagjai helyenként egymás közelében maradtak, pontosabban szólva, köztük a térbeli távolság mindig kisebbnek mutatkozott, mint más európai (és észak- amerikai) nagyvárosokban. E társadalmi összekeveredés közvetlenül összefüggött a bérházak e két városban megfigyelhetô általános elterjedtségével. A wilhelmiánus Berlinben, szimptomatikusan, nem találni egyetlen olyan kerületet, ahol a munkáslakások aránya meghaladta volna a teljes lakásállomány $80 \%$-át; ugyanakkor meglepôen gyakoriak a kevert lakótársadalmú bérházak. Az egyetlen épületen belüli társadalmi sokféleség sưrü elớfordulása annak is eredménye, hogy Berlin Haussmann-ja, James Hobrecht csökönyösen pártolta a közép-és a munkásosztály által együttesen lakott bérház típusát. Úgy vélte, hogy a különbözô rétegek így megvalósuló térbeli közelsége hozzájárulhat gazdag és szegény megbékéléséhez, a közöttük gyakori konfliktusok, ellenségeskedések könnyebb elsimíthatóságához (Liang 1976).

Nem tudni, volt-e ehhez fogható eszmei forrása a kevert lakóközösségũ bérházak budapesti meghonosításának. Tény viszont, hogy ha fổleg nem is a külvárosokban, az ott álló bérkaszárnyákban, hanem a belsô városrészek kevésbé rangos bérpalotáiban (és ezeken a területeken ezek alkották a többséget), különbözố társadalmi rétegek képviselổi egyidejüleg voltak jelen egyazon lakóházban. Nemcsak a mellékutcák szerényebb épületeire érvényes ez, hanem még a Nagykörút legtöbb bérházára is. Helyesen summázza Hanák Péter, miszerint: ,,A magán- 
szféra szoros elkülönítésének és az alsóbb néposztályoktól való minél teljesebb elkülönülésének burzsoá elve Budapesten kevésbé érvényesült, mint Nyugat- és Közép-Európa egyéb nagyvárosaiban. Az udvari lakásokban ... kispolgári családok, hátul pedig munkások, szegény emberek éltek együtt gazdag polgárral, sốt bizonyos fokig az életébe is beláttak."' Mindebbốl azonban nem következik, hogy minden budapesti bérház, kivált bérpalota bẻrlốközössége kevert lett volna (Gyáni 1978). S még kevésbé kell ebbôl arra gondolni, hogy a magyar fốvárosban nem léteztek masszívan munkáslakta kerületek, olyan proletárgócok, amelyek mégiscsak a munkások többségének szolgáltak lakhelyül. Igaz viszont, hogy a legkoncentráltabban munkáslakta Kốbánya és Óbuda területén is kevesebb a munkáslakások aránya 80 \%-nál (1911), s hogy még a két világháború között is, amikor pedig nôtt a szegregáció mértéke, Angyalföldön az egyszobás lakások aránya 84 \% körüli (1935), bár nem minden szoba-konyhás lakás bérlổje tartozott a munkásság soraihoz (Gyáni é. n.).

Az imént említett városok között észlelhetố különbségek további árnyalása sem teheti kétségessé, hogy a fejlett európai és észak-amerikai metropoliszok mindegyikében nớtt és megszilárdult a rétegek szegregációja. S ebben az összefüggésben komoly súlya van annak, hogy belvárosi vagy munkások lakta külvárosi negyed utcáját, közterét vizsgáljuk-e. Például azért, mert már csupán a fekvésüktốl függôen más és más funkciók hordozói lehettek e nyilvános térségek. A belváros széles, reprezentatív középületekkel szegélyezett sugár-és körútjai , nyertek” felhatalmazást arra, hogy szakrális közösségi-politikai eseményeknek szolgáljanak színhelyül: itt rendezték (rendezik ma is) a nyilvános ünnepségeket, tömegfelvonulásokat, katonai parádékat, szóval a hatalom által kezdeményezett és jóváhagyott ceremóniákat, közösségi rituálékat. Ehhez fogható nyilvánosság-funkcióval a külvárosok lakónegyedeinek az utcái (terei) közül természetszerúleg egy sem rendelkezhetett.

Továbbá: eltértek egymástól abban is, hogy amíg a belváros útjain, utcáin, közterein az élet, a nyilvános megjelenés hétköznap is inkább tartotta magát a polgári mércékhez, amelynek a csendben maradás, az önfegyelem, a szociabilitás minimálisra korlátozása képezi a lényegét, addig a külvárosok nyilvános térségein erôszakkal kellett annak valamelyest is érvényt szerezni. Ennek egynémely vonatkozásáról szólnék a tanulmány utolsó részében.

\section{Kié az utca?}

Az utca mint köztér használatát hagyományosan az szabta meg, hogy tág lehetôség nyîlt az informális élet, a társaslét szociabilitásának itteni kiélésére. E hagyomány élesen szembekerült a köztér szabályozásának, tulajdonképpeni semlegesítésének azzal az elképzelésével, amely a hatóságokat kezdte átitatni a 19. század elejétól és még inkább közepétốl. Angliában pl. az utcai köztér használatát illetổ korábbi egyetértés a múlt század derekán kezd megbomlani, amikor megkezdổik az utca hatósági ,,igazgatása”. Ennek a jegyében egyre-másra látnak napvilágot az utca rendjérốl intézkedô városi szabályzatok (Daunton 1983). De ide nyúlik vissza a városi rendổrség korabeli szervezeti kiépítése és a rendốri tevékenység fogalmának a radikális kitágítása is. Ezekkel a lépésekkel kezdetét vette az utca polgári kódjának, mint általánosan érvényes (és kötelezố) normának a ráerôszakolása a társadalom széles tömegeire. Ami azután gyakran közvetlen beavatkozást tett szükségessé az egyes emberek és szükebb közösségek életé- 
be, magánautonómiájába. A század derekán az észak- angliai városokban például ,,a rendốrség fellépése azt a hatást keltette, hogy támadás éri a hagyományosan szentesített szabadságot az utcai csoportosulás szabadságát... A rendốr szokványos felszólítására (tovább, tovább!) reagáló tömeges attitũd nyugodtan besorolható a munkásosztály engedetlenségi viselkedésformái közé". ${ }^{8}$

A rendổ beavatkozása a nyilvános élet vitelébe nemcsak hogy intenzívvé vált, de a jellege is megváltozott. , A 'kényszer-akkulturáció-ként is nevezhetõ felügyelet hatékonyságát fokozandó az elszórt, erốszakra hagyatkozó ellenốrzést felváltotta az a fajta rendốri fegyelmezés, amely a szüntelen felügyelet nyomásának tette ki a népességet. Ez a hatalomérvényesítés megköveteli a hatalom képviselôjének, a rendổrnek mindenkori fizikai jelenlétét, fürkészô-vizslató tekintetének irritáló állandóságát, hogy mindenkiben meggyökereztesse annak tudatát, hogy a rendôr mindig a közelben van és bármikor a helyszínen teremhet" (Storch 1975-76). A fegyelmezésnek ez a metódusa a Bentham-i panoptikumban rejlổ hatalom-technikai elvet viszi át a napi gyakorlatba, $\mathrm{s}$ mint ilyen, hamisítatlan normalizáló-mikrohatalmi stratégiának fogható fel (Foucault 1979).

A szüntelenül fürkészổ rendốri tekintet azonban csak akkor lehet igazán hatékony, ha vizuálisan uralhatja a felügyeletére bízott terepet, és egyúttal képes eligazodni a fegyelmezendố idegenek világában. A városi terep áttekinthetôségét megkönnyítette a széles és egyenes utcák rendszere. Arra, hogy mennyire nagy súlyt nyert a rendốri pillantás akadályainak lehetố kiküszöbölése, egyetlen példát említek. Amikor Budapesten vita alakult ki az 1880-as években a rendốrség, valamint a kávéháztulajdonosok között arról, hogy vajon a kávéházak elfoglalhatjáke a maguk céljaira a járda egy részét, bekerítvén azt a részt, ahová asztalokat és székeket helyeznek ki, a megoldást hevesen ellenzổ rendôrség egyik érve így szólt: ,, miután a rendốri közegek létszáma nem engedi meg, hogy minden egyes bekerített üzlet elé ởrszem állíttassék, a távolabb álló ốrnek az utcza áttekintése, ezen bekerítés által, igen megnehezíttetik, sốt lehetetlenné tétetik", minek következtében "éjjeli csavargók és gyanús egyének, az ốket szemmel tartó rendốr elổ, ezekben alkalmas búvó helyeket találnak...”. ${ }^{9}$ Megjegyzem: a városi tanács, némi tanácstalanság után, végül engedélyezte a járdarészek bekerítését. Ami a másodikként említett feltételt illeti, az általános problémát érint. Volt már arról szó, hogy a városi ,,szöveg", az idegenek alkotta nagyváros kaotikus világa mind kevésbé érthetố, értelmezhetô pusztán vizuális jelek alapján. A rendôr viszont ahhoz, hogy feladatának megfelelhessen, pusztán vagy döntổ mértékben az iskolázott tekintet megismerô (tájékozódó) képességében bízhat, ez legfốbb eszköze. Hogy milyen jelentôsége volt a korban a rendốri tekintet ,,intelligenssé" tételének, azt egy philadelphiai példán mutatom be. „A járôröknek szükségük volt valamilyen módszerre, hogy egyetlen pillantással eldöntsék az illetô társadalmi állását. Azok az amerikaiak, akik igyekeztek megszabni, hogy kit tartóztasson le a rendổrség, fổként a ruházatban jelölték meg a szociabilitás megnyilvánulását. A viselet jól megválasztott együttese ti. megmutatta, hogy viselổje tisztában van a 'rend, a rendszeresség és a jó idôbeosztás' értékével ... Az viszont, aki slamposan öltözködik, a közönségre nézve potenciálisan veszélyt jelenthet, az ilyeneket tehát a rendôrségnek gondosan szemmel kell tartani. A külsố megjelenést iránytúként kezelve az alkalmazottak így gyorsan azonosíthatták, $\mathbf{s}$ nyomban az ellenôrzésük alá is vonhatták a társadalom jólétét veszélyeztetốket." 10

Az utca személytelenné tétele a ,,morális reform" ügybuzgó végrehajtóiként ténykedố rendốröknek fontos feladatát képezte. Az utcai és egyéb közterek ilyen értelmú semlegesítését szám- 
talan példán illusztrálhatjuk. Közülük az egyik legszélsôségesebb az, amely szerint a berlini bérkaszárnyák egyikében-másikában a tulajdonos házirendbe foglalt tiltással illette a gyerekek udvari játszadozását, vagy a bérlốk azon szokását, hogy a lakásukban facipốt hordjanak, az ablakpárkányokra virágokat helyezzenek vagy kiálljanak a gangra és a lépcsốházban beszélgessenek (Ling 1976). A magán- és a közszférának az efféle tiltásokban kifejeződô végletes téri szétválasztására példa az is, hogy Philadelphia-ban, szintén a múlt század derekán, a rendốr kötelességévé tették az olyan utcán talált részeg ổrszobai elzárását, aki nem tudott számot adni a nevérôl és a lakcímérôl. Így kívánták elejét venni, hogy az illetố privát életfunkcióját, az alvást köztéren, az utcán oldja meg (Johnson 1979).

De túl az említetteken, az utcai nyilvánosság terjedelmét is másként határolja körül a viselkedés új polgári felfogása, mint a továbbélố népi hagyomány. Egyebek között legitimitását kezdi veszteni az utcai árusítás vagy szórakozás, amely specializált közterek illetékességébe kerül át (bolt, piaci csarnok, szórakoztató intézmények). Szabályrendeletek garmadájával igyekszik a hatóság gátat vetni az utcai árusok ténykedésének éppúgy, mint az utcai zenészek müködésének a századközép Angliájában. És hasonlóképpen tilalomlistára kerülnek a fổeg fiatalokat megmozgató utcai játékok és sportok, az utcán ûzött futballozás, birkózás és a többi közösségi esemény (Daunton 1983; Green 1982).

Nem követjük most tovább a történetet, amely a köztér fogalma, használatának joga és illetékessége körüli szüntelen vita és konfliktusok sorozata úgyszólván mind a mai napig. Hadd emlékeztessek csupán egyetlen mozzanatra: nem is olyan régen született egy - azóta visszavont - parlamenti rendelkezés Magyarországon, amely megtiltotta a Parlament épülete körüli fórumszerú tér használatát tömegdemonstrációk céljaira. S ezzel a köztér politikai célokra történố kisajátításának a témájához érkeztünk, amely azonban külön vizsgálódást kíván.

\section{Jegyzetek}

' Ariés, P. (1987) A gyermek és a családi élet az ancien régime korában. In: uớ: Gyermek, család, halál. Tanulmányok. (Budapest: Gondolat) 213-214.

${ }^{2}$ Zola nevezi így a 19. század vége felé Párizst. Lásd Vidler, A. (1978) The Scenes of the Street: Transformations in Ideal and Reality, 1750-1871. In: S. Anderson (ed.): On Streets (Cambridge: Mass) 100.

${ }^{3}$ Folguera, P. (1985) City Space and the Daily Life of Women in Madrid in the 1920s. Oral History Journal, vol. 13. no. 2. 53 .

4 Engels, F. (1969): A lakáskérdéshez. MEM 18. kötet, Budapest, 246.

${ }^{3}$ Shapiro, A. L. (1985) Housing the Poor of Paris 1850-1902. (Madison) 159.

- Olsen, D. J. (1986) The City as a Work of Art. London, Paris, Vienna (London: New Haven) 147.

${ }^{7}$ Hanák P. (1988) Polgárosodás és urbanizáció. Bécs és Budapest városfejlôdése a 19. században. In: A Kert és a Mühely (Budapest: Gondolat)

- Storch, R. D. (1975-76) The Policeman as Domestic Missionary: Urban Discipline and Popular Culture in Northern England 1850-80. Journal of Social History, IX. 482.

' Budapest Fớváros Levéltára IV. 1407. b. 465/1874-VII.

${ }^{10}$ Johnson, D. R. (1979) Policing the Urban Underworld. The Impact of Crime on the Development of the American Police, 1800-1887. (Philadelphia) 


\section{Irodalom}

Ariés, P. (1987) A gyermek és a családi élet az ancien régime korában. In: uõ.: Gyermek, család, halál. Tanulmányok (Budapest: Gondolat) 213-214.

Bedarida, F. - Sutcliffe, A. (1980) The Street in the Structure and Life of the City. Reflections on Nineteenth-Century London and Paris. Journal of Urban History, vol. 6. No. 4.

Berman, M. (1982) All That is Solid Melts Into Air. The Experience of Modernity. New York, 159.

Clark, C. E. jr. (1976) Domestic Architecture as an Index to Social History: the Romantic Revival and the Cult of Domesticity in America, 1840-70. Journal of Interdisciplinary History, vol. 7.

Daunton, M. J. (1983) House and Home in the Victorian City. Working-Class Housing 1850-1914. (London: Edward Arnold)

Daunton, M. J. (1989) The Social Meaning of Space: The City in the West and Islam. (Kézirat)

Evans, R. J. (1988) Past and Pressent, Epidemics and Revolutions: Cholera in Nineteenth-Century Europe. 120.

Folguera, P. (1985) City Space and the Daily Life of Women in Madrid in the 1920s. Oral History Journal, vol. 13, no. 2.53.

Foucault, M. (1979) Discipline and Punish. The Birth of the Prison, (London: Harmondsworth)

Green, D. R. (1982) Street Trading in London: A Case Study of Casual Labour, 1830-60. In: J. H. Johnson - C. G. Pooley (eds.): The Structure of Nineteenth Century Cities (London: Croom Helm) 139-147.

Grier, K. C. (1989) Culture and Comfort: People, Parlors, and Upholstery, 1850-1930 (University of Massachusetts Press)

Gyáni, G. (1978) Egy lipótvárosi ház lakói a huszas évek elején, Budapest. 9. sz.

Gyáni, G. (1989) Domestic Culture of the Upper-Middle Class in Budapest, 19th Century, Elóadás az 5. Angol-magyar történészkonferencián.

Gyáni, G. (é. n.) Nyomortelep és bérkaszárnya. A budapesti munkáslakás múltja. (Budapest: Magvetô) Megjelenés előtt.

Hanák, P. (1985) A Ringstrasse és a Nagykörút. Bécs és Budapest városfejlôdésének összehasonlítása. Világosság 2.

Hanák, P. (1988) Polgárosodás és urbanizáció. Bécs és Budapest városfejlódése a 19. században. In uõ.: A Kert és a Mühely. (Budapest: Gondolat)

Hohenberg, P. M. - Lees, L. H. (1985) The Making of Urban Europe 1000-1950. Cambridge: Mass.

Johnson, D. R. (1979) Policing the Urban Underworld. The Impact of Crime on the Development of the American Police, 1800-1887. (Philadelphia)

Jones, G. S. (1984²) Outcast London. A Study in the Relationship Between Classes in Victorian Society. (New York)

Liang, H. H. (1976) Lower-Class Immigrants in Wilhelmine Berlin. In: A. Lees - L. Lees (eds.) The Urbanization of European Society in the Nineteenth Century. (Lexington, Mass.) 219-221.

Lofland, L. H. (1973) A World of Strangers. Order and Action in Urban Public Space (New York: Basic Books)

Olsen, D. J. (1986) The city as a Work of Art. London, Paris, Vienna (London - New Haven) 147.

Schorske, C. E. $\left(1981^{2}\right)$ Fin-de Siécle Vienna. Politics and Culture (New York)

Sennett, R. (1977) The Fall of Public Man. On the Social Psychology of Capitalism (New York: Vintage Books)

Shapiro, A. L. (1985) Housing the Poor of Paris, 1850-1902. (Madison) 159.

Storch, R. D. (1975-76) The Policeman as Domestic Missionary: Urban Discipline and Popular Culture in Northern England 1850-80. Journal of Social History, IX.

Sutcliffe, A. (1979) Environmental Control and Planning in European Capitals 1850-1914: London, Paris and Berlin. In: I. Hammerström - T. Hall (eds.): Growth and Tranformation of the Modern City. Stockholm, 89.

Vidler, A. (1978) The Scenes of the Street: Transformations in Ideal and Reality, 1750-1871. In: S. Anderson (ed.): On Streets (Cambridge: Mass.) 100. 


\title{
A SOCIAL HISTORY OF URBAN SPACE
}

\author{
Gábor Gyáni
}

Mainstream studies of urban space follow the traditions of the Chicago School still nowadays. Accordingly, their research topic is the residential segregation of population in large cities and related population moves. But urban space can also be studied in a different perspective: it can be examined as a scene of the most varied-individual and public-activities and can be considered in the light of values and norms related to its use. The present paper adopted the latter approach and places the counterconcepts (dichotomy) of the public and private, as well as the varied forms of social space conforming to these concepts, into the focus of analysis.

From the mid-18th century onwards, the spheres of public and private have been gradually growing apart in the western countries of Europe. The present paper traces the functional transformation of the public in large cities. As a result of that process, the metropolitan public, particularly the public of streets, has become impersonal and turned into a neutral , space". The separation of the public and private is clearly visible both in the spatial structure and the building stock of large cities. This is a direct consequence of tendentious urban planning concepts patterned after Haussman's remodelling Paris in the second half of the 19th century. The metropolis thus reborn, through the inventions of boulevards and theoroughfares, having a symbolic value, could serve both the practical needs of use by ever growing masses of people, the functions of traffic, and a new kind of need for the impersonal outdoor public. At the same time, public and semi-public spaces were mushrooming all over to serve the needs of strangers, the individuals of the metropolitan masses, for being in public.

The dichotomy of public and private has evolved even within the private sphere: the family and the home. There is a distinct division in the spacious dwellings of the middle- and uppermiddle-class between living-spaces of family members and domestic aids; and an isolated use of space by sex and age within the family has also soon become general. Finally: some , family rooms", primarily the bedroom, served strictly and specifically the needs of privacy, while others, like the parlour, were explicitely reserved for social life.

Bringing about and controlling the impersonal and neutral character of the street has also become an official task. The official-police supervision of population has become particularly pressing in the living districts of lower social strata in order to make their residents respect the bourgeois code of behaviour in public. All this indicates, at least indirectly, that social orientation within cities reaching giant proportions, where urban community is becoming a mass society, is getting more and more a matter of orientation by spatial location. In the world of strangers, the knowledge required by everyday living cannot solely rely on the routine of a trained eye, the ,,reading" of the urban "texture" depends on the urbanites' awareness of where is what and who. 
One of the direct causes arousing increased official control was a different, from the bourgeois norms, notion attributed to the use of space by certain social groups and subcultures and their limits of behaviour in public being placed somewhere else. This is emphasized by the fact that in a modern metropolis, partly as a result of tendentious urban planning interventions, social groups are more segregated than earlier. Segregation was used, among others, for prevention from revolving epidemics (cholera) which, due to their spatial vicinity, also afflicted the upper classes. The (inner) city and the workers' peripheral residential distritcs were therefore also significantly dissimilar as symbolic spaces. The city had sacral and ceremonial functions while peripheries could not gain such an acceptation, for the very reason that the informal looseness or indecency of street-life there has been for long preserved, in spite of official fights against it. The institutionalization of municipal police in most European cities in the middle of last century was largely derived from the requirement of a close and constant control over public places in these districts. Police supervision of the time, saturated with the ethos of bourgeois moral standards, was called to neutralize and impersonalize the public in these parts of the city.

The ,efficiency" of police work was strongly dependent on the extent to which the urban "texture" was intelligible in a policeman's eyes; on how much a supervisor of the public sphere could be trained to become familiar, also visually, with the city. Besides, there were, of course, municipal regulations in large number intended to enforce the norms of bourgeois behaviour. These regulations and the policemen, who act for their implementation, confine the life func-. tions, which are visible for the widest public, to an ever smaller circle and thereby compel community members to sequester themselves, for enjoying public life, in newly mushrooming specific micro spaces, public or semi-public places, specialized to fulfil one single function.

Transl. E. Daróczi 